\title{
High performance biocatalyst based on $\beta$-D-galactosidase immobilized on mesoporous silica/titania/chitosan material
}

\author{
Natália Carminatti Ricardi ${ }^{a}$, Leliz Ticona Arenas ${ }^{a}$, Edilson Valmir Benvenutti ${ }^{a}$, Ruth Hinrichs ${ }^{b}$, \\ Elí Emanuel Esparza Flores ${ }^{c}$, Plinho Francisco Hertz ${ }^{c}$, Tania Maria Haas Costa ${ }^{a, *}$ \\ ${ }^{a}$ Instituto de Química (IQ), Universidade Federal do Rio Grande do Sul (UFRGS), Porto Alegre, RS, Brazil \\ ${ }^{\mathrm{b}}$ Instituto de Geociências (IGEO), Universidade Federal do Rio Grande do Sul (UFRGS), Porto Alegre, RS, Brazil \\ ${ }^{\mathrm{c}}$ Instituto de Ciência e Tecnologia de Alimentos (ICTA), Universidade Federal do Rio Grande do Sul (UFRGS), Porto Alegre, RS, Brazil
}

\section{A R T I C L E I N F O}

\section{Keywords:}

Supported biocatalyst

Chitosan

Lactose hydrolysis

Hybrid organic inorganic material

Enzymatic catalysis

\begin{abstract}
A B S T R A C T
A new support for the immobilization of $\beta$-D-galactosidase from Kluyveromyces lactis was developed, consisting of mesoporous silica/titania with a chitosan coating. This support presents a high available surface area and adequate pore size for optimizing the immobilization efficiency of the enzyme and, furthermore, maintaining its activity. The obtained supported biocatalyst was applied in enzyme hydrolytic activity tests with $o$-NPG, showing high activity $1223 \mathrm{Ug}^{-1}$, excellent efficiency (74\%), and activity recovery (54\%). Tests of lactose hydrolysis in a continuous flow reactor showed that during 14 days operation, the biocatalyst maintained full enzymatic activity. In a batch system, after 15 cycles, it retained approximately $90 \%$ of its initial catalytic activity and attained full conversion of the lactose $100 \%( \pm 12 \%)$. Additionally, with the use of the mesoporous silica/titania support, the biocatalyst presented no deformation and fragmentation, in both systems, demonstrating high operational stability and appropriate properties for applications in food manufacturing.
\end{abstract}

\section{Introduction}

The use of enzyme has become a powerful strategy to replace inorganic catalysts in the search for alternative methodologies in industrial processes. The advantages of using biocatalysts range from their high activity, specificity, and selectivity, to their general operation in milder temperature, pressure, and $\mathrm{pH}$ conditions, being considered eco-friendly alternatives for high value chemical synthesis (Chapman, Ismail, \& Dinu, 2018; Madhavan, Sindhu, Binod, Sukumaran, \& Pandey, 2017). Enzymes are, in general, applied in free conditions, which hinders their recuperation and reutilization. These drawbacks can be solved by the immobilization of the enzymes on solid supports, so improving the biocatalyst's stability under storage and operational conditions such as thermal and $\mathrm{pH}$. The enzyme immobilization reduces costs, enabling the recovery of the biocatalyst (separation from the product) and its reutilization (Bilal et al., 2018; Sheldon \& van Pelt, 2013). Therefore, the immobilization of enzymes has become a requirement for the use of biocatalysts in industrial operations since it improves the reaction control, avoids protein contamination of the product by easy separation, and enables the use of continuous flow biocatalysis reactors (Garcia-
Galan, Berenguer-Murcia, Fernandez-Lafuente, \& Rodrigues, 2011; Schöffer, Klein, Rodrigues, \& Hertz, 2013). A better performance of the biocatalyst can be obtained by optimizing the immobilization process and combining the biochemical properties of the enzyme with the characteristics of the support (Bolivar, Consolati, Mayr, \& Nidetzky, 2013).

$\beta$-D-galactosidase (E.C.3.2.1.23) is a glycoside hydrolase enzyme that catalyzes the hydrolysis of lactose by breaking glycosidic bonds to yield glucose and galactose. This enzyme holds great promise in food technology for the preparation of low-dosage lactose or lactose-free products, and the production of trans-galactosylation products or galactooligosaccharides (GOS) (Li et al., 2019; Xavier, Ramana, \& Sharma, 2018). Several methods for enzyme immobilization have been proposed for $\beta$-D-galactosidase (Grosová, Rosenberg, \& Rebroš, 2008), including enzyme cross-linking (Xu, Ji, Deng, \& Agyei, 2020), characterized by the formation of covalent bonds between protein molecules by the use of bifunctional reagents. However, it has some drawbacks including limitations in mass transfer and loss of catalytic activity. Another method is the adsorption (Wolf \& Paulino, 2019), which occurs by physical adsorption of the enzyme on a solid support but has a

\footnotetext{
* Corresponding author.

E-mail address: taniaha@iq.ufrgs.br (T.M.H. Costa).
} 
disadvantage in the low stability of the immobilized enzymes which leads to their leaching from the support. Finally, there is the covalent binding (Banjanac et al., 2016), which is formed by chemical bonds between amino acid side-chains of the enzymes to the functionalized surface of organic and inorganic supports. One of the main benefits achieved with covalent immobilization of enzymes is the potential to improve the catalyst's useful life due to the greater stability of the bond, and consequent decrease in the leaching of the enzyme from the support, leading to an increase in the operational stability of the immobilized enzyme (Grosová, Rosenberg, \& Rebroš, 2008). This method was chosen to be applied in the present work.

Chitosan is a natural polysaccharide obtained by the partial deacetylation of chitin. Chitosan-based materials are applied as enzyme immobilization supports due to their polycationic, nontoxic, biocompatible, and biodegradable properties, and because they present reactive amino and hydroxyl groups that are available for chemical modifications (Krajewska, 2004). The use of chitosan as a support for enzyme immobilization has increased due to the possibility of obtaining it in the form of microspheres, membranes, coatings, and gels (Bilal \& Iqbal, 2019). To enable the covalent attachment of the enzyme to the support, it is necessary to activate the matrix with a bifunctional reagent, such as glutaraldehyde, whose terminal functional groups (-CHO) simultaneously react with the binding sites of chitosan $\left(-\mathrm{NH}_{2}\right)$ and the terminal amino group of the enzyme. Urrutia, Bernal, Wilson and Illanes (2018) studied the immobilization of $\beta$-D-galactosidase in chitosan particles functionalized with glutaraldehyde and epichlorohydrin, and tested it in galacto-oligosaccharides synthesis. Other authors (de Albuquerque et al., 2018; Klein et al., 2012) reported the immobilization of $\beta$-Dgalactosidase in chitosan spheres, showing great enzyme activity and high stability. However, supports based on chitosan suffer from low mechanical stability, which causes their deformation and disintegration when applied in reactors and continuous processes. Therefore, mechanical properties of chitosan supports have to be improved to hamper their deformation and enable their application in the food industry.

Inorganic oxides, such as silica, have interesting properties for the immobilization of enzymes due to their high thermal and mechanical resistance, posing no risk to health. Important textural properties, such as pore volume and pore size, can be designed by the production process and the surface of the oxides can be modified by the insertion of functional groups, which enable the immobilization of enzymes by several techniques such as adsorption and covalent binding. More recently, systems containing magnetic particles have been developed, so opening new perspectives (Rimola, Costa, Sodupe, Lambert, \& Ugliengo, 2013; Xie \& Zang, 2017; Zucca \& Sanjust, 2014). Therefore, inorganic matrices with a planned texture, and coated with organic functional components, seem to be an excellent choice as supports for the immobilization of enzymes in enzymatic catalysis. This support will allow the combination of the properties of the inorganic and organic components, such as the textural, thermal, and mechanical stability from the inorganic component (oxide), and the biocompatibility and specific functional group reactivity from the organic fragment (chitosan) (El Kadib \& Bousmina, 2012). A previous study (Ricardi et al., 2018) addressed the preparation of a silica chitosan composite as support for $\beta$-D-galactosidase covalent immobilization. However, even though the proposed system proved to be efficient in the hydrolysis of lactose, in this support the chitosan became distributed in micrometric domains where the immobilization of the enzyme in fact occurred. The direct immobilization of the enzyme on the silica moiety was not possible because it contained only hydroxyl groups, which are not adequate for the $\beta$-D-galactosidase immobilization. Therefore, the dispersion of chitosan at a molecular level, and to a greater extent in a porous support, is expected to increase the maintenance of the structural and functional properties of the enzyme.

Mixed silica/titania can be a more effective choice for the immobilization of biomolecules, due to the interaction of Lewis acid sites of the titania moiety with the basic nitrogen atom of the $\mathrm{NH}_{2}$ group in biomolecules, allowing the adsorption of species (both chitosan and enzymes), without the need of functionalization (El Kadib, Molvinger, Guimon, Quignard, \& Brunel, 2008). Magnetic silica/titania and silica/ titania graphite composites modified with chitosan have been reported as supports for the direct immobilization of tyrosinase (Laranjo et al., 2019; Morawski et al., 2018). These materials were applied to the preparation of electrochemical biosensors. However, except for biosensor applications, to our knowledge there are no reports of mixed silica/titania modified with chitosan supports being applied to enzymatic catalysis.

In this work, silica/titania materials with adequate pore size for enzyme immobilization and improved activity were developed. Considering the affinity of the enzyme for the chitosan moiety, the porous silica/titania materials were modified with this biopolymer, using a method that seeks a thorough surface covering so enlarging the available area for enzyme immobilization. This composite material was used as support for $\beta$-D-galactosidase immobilization for the first time. For the sake of comparison, a porous silica/titania material without using cross linking agents was used as an enzyme support as well. Both prepared supported biocatalysts were applied in enzyme hydrolytic activity tests with $o$-NPG, in consecutive batch cycles, and in the lactose hydrolysis reactions in a continuous fixed bed reactor, and their immobilization parameters, temperature, $\mathrm{pH}$, and operational stability were investigated afterwards.

\section{Materials and methods}

\subsection{Materials}

Tetraethyl orthosilicate (TEOS, 98\%, Sigma-Aldrich, Germany), titanium(IV) isopropoxide (TIPOT, 97\%, Sigma-Aldrich, USA), hydrochloric acid ( $\mathrm{HCl}, 37 \%$, Emsure Merck, Germany), hydrofluoric acid (HF, 40\%, Sigma-Aldrich, USA), ethanol (99.9\%, Emsure Merck, USA), chitosan low molecular weight (75-85\% deacetylated, Sigma-Aldrich, USA), glutaraldehyde (25\%, Sigma-Aldrich, USA) and sodium hydroxide $(99.5 \%$, Dinâmica, Brazil) were used in the synthesis of the support. Kluyveromyces lactis $\beta$-D-galactosidase (Maxilact LX-5000, Globalfood, Brazil) is the tested enzyme. $o$-nitrophenyl $\beta$-D-galactopyranoside (oNPG, Sigma-Aldrich, Germany), potassium phosphate monobasic anhydrous (99.5\%, Nuclear, Brazil), potassium phosphate dibasic anhydrous (99.5\%, Nuclear, Brazil), sodium carbonate (99.5\%, Neon, Brazil), sodium bicarbonate (99\%, Neon, Brazil), sodium chloride (99.5\%, Nuclear, Brazil), magnesium chloride (99.5\%, Synth, Brazil), ethylene glycol (99.5\%, Dinâmica, Brazil), D-(+)-lactose (Dinâmica, Brazil) and the D-glucose determination kit (In Vitro Diagnóstica) were used as a substrate for the enzyme performance evaluation. All reagents were of analytical grade without further purification and all solutions were prepared with distilled water.

\subsection{Preparation of the silica/titania supports and immobilization of $\beta$-D- galactosidase}

The supported biocatalysts were prepared according to the steps shown in Fig. S1, Supplementary Material. The first step was the preparation of the silica/titania material using sol-gel synthesis, with the purpose of obtaining $70 \%$ and $30 \% \mathrm{~mol} / \mathrm{mol}$ of silica and titania similar to the material proposed by other authors (Laranjo et al., 2019). Firstly, the hydrolysis of the precursor was performed by adding TEOS ( $5 \mathrm{~mL}$ ) to the solvent (ethanol, $7.0 \mathrm{~mL})$. Then water $(0.6 \mathrm{~mL})$ and $\mathrm{HCl} 37 \%(0.2$ $\mathrm{mL}$ ) were added and the solution was stirred magnetically for $1 \mathrm{~h}$. In sequence, TIPOT $(2.0 \mathrm{~mL})$ and a mixture of the catalysts, HF $40 \%(1.5$ $\mathrm{mL})$ and $\mathrm{HCl} 37 \%(1.0 \mathrm{~mL})$ were added to this solution. The system was left at ambient conditions for 15 days for gelation and solvent evaporation and the obtained material was comminuted (Tyler standard sieve 80 mesh), washed to neutral $\mathrm{pH}$ and then vacuum-dried at $90^{\circ} \mathrm{C}$ for $2 \mathrm{~h}$. This porous powder is henceforth called SiTi.

Two supported biocatalysts were produced based on SiTi: i) SiTienz 
was prepared by direct immobilization of the $\beta$-D-galactosidase (see left hand side of the diagram in Fig. S1); ii) SiTi-CHenz was prepared by a three step procedure (see right hand side of the diagram). Firstly, the support SiTi was covered with chitosan. The silica/titania surface was modified with chitosan by a grafting reaction, based on an already reported method (Laranjo et al., 2019). $150 \mathrm{mg}$ of chitosan were dissolved in water $(10 \mathrm{~mL})$ and $\mathrm{HF} 40 \%(0.3 \mathrm{~mL})$ under constant stirring until homogenization. $\mathrm{NaOH}\left(0.1 \mathrm{~mol} \mathrm{~L}^{-1}\right)$ was added to this solution until it reached $\mathrm{pH}$ 6, and finally $1.0 \mathrm{~g}$ of the SiTi was added to this mixture, which remained under magnetic stirring for $24 \mathrm{~h}$. The resulting material was washed with portions of water and ethanol, and vacuum-dried for 2 h. This sample was designated SiTi-CH. In sequence the SiTi-CH was activated with glutaraldehyde. The material was incubated in a solution containing $0.1 \mathrm{mmol}$ of glutaraldehyde per gram of material for three hours under agitation. The activated support was abundantly washed with water to remove the excess glutaraldehyde and then vacuum-dried for $2 \mathrm{~h}$. In this intermediate stage, the support was denominated as SiTiCHglut.

For the $\beta$-D-galactosidase immobilization, $1.0 \mathrm{~mL}$ of $0.1 \mathrm{mg} \mathrm{mL}^{-1}$ enzyme solution in immobilization buffer $\left(0.1 \mathrm{~mol} \mathrm{~L}^{-1}\right.$ potassium phosphate buffer, $\mathrm{pH} 7.0$, containing $1.5 \mathrm{mmol} \mathrm{L}^{-1} \mathrm{MgCl}_{2}$ ) was added to 10 $\mathrm{mg}$ of the supports SiTi and SiTi-CHglut. The suspensions were mixed overnight $(18 \mathrm{~h})$ in an orbital shaker at room temperature $\left(25^{\circ} \mathrm{C}\right)$. To remove the unbound proteins, the materials were sequentially washed with an activity buffer, $\mathrm{NaCl}\left(1 \mathrm{~mol} \mathrm{~L}^{-1}\right)$ and ethylene glycol $(30 \% \mathrm{v} / \mathrm{v})$. These complete biocatalysts were denominated SiTienz and SiTi-CHenz, respectively.

\subsection{Materials characterization}

The micrographs were obtained using a field emission scanning electron microscope (FE-SEM) (FEI Inspect F50) operating at $20 \mathrm{kV}$, on powder samples dispersed on double-sided conductive tape and coated with a thin gold layer. Elemental analysis was accomplished with an energy dispersive X-ray spectrometer (Thermo-Fisher) coupled to a scanning electron microscope (JEOL LV5800). For this analysis the powder was compacted to pellets $\left(4.6\right.$ ton $\mathrm{cm}^{-2}$ ) and the $\mathrm{SiO}_{2}$ and $\mathrm{TiO}_{2}$ content was obtained with quantification procedures that used top-hat filter for background removal and $\varphi(\rho \mathrm{Z})$ matrix correction. The powder XRD patterns were obtained in the $5^{\circ}$ to $90^{\circ} 2 \theta$ range, using $\mathrm{Cu}-\mathrm{K} \alpha$ radiation in a Siemens diffractometer (BRUKER AXS D-5000) operating at $40 \mathrm{kV} / 25 \mathrm{~mA}$, with a graphite monochromator in the secondary beam. The samples were analyzed at $0.05^{\circ} \mathrm{s}^{-1}$. Thermogravimetric analysis (TGA) was carried out using a Shimadzu equipment (TGA-50), under argon flow of $50 \mathrm{~mL} \mathrm{~min}^{-1}$ and a heating rate of $20^{\circ} \mathrm{C} \mathrm{min}{ }^{-1}$, from room temperature up to $850{ }^{\circ} \mathrm{C}$. The nitrogen adsorption/desorption isotherms were acquired at liquid $\mathrm{N}_{2}$ boiling point $(77 \mathrm{~K}$ ), in a Micromeritics instrument (Tristar II 3020 with Krypton option). $100.0 \mathrm{mg}$ of each sample were previously degassed at $60{ }^{\circ} \mathrm{C}$ for $8 \mathrm{~h}$. The specific surface area was calculated by the Brunauer, Emmett and Teller method (BET), and the pore-size distribution curves were obtained by using the Barret, Joyner and Halenda method (BJH) (Gregg \& Sing, 1982; Webb \& Orr, 1997). Fourier transform infrared spectroscopy (FT-IR) spectra were performed between 500 and $4000 \mathrm{~cm}^{-1}$, using 68 scans, with a Perkin Elmer spectrophotometer (Spectrum 1000 FT-IR), using the $\mathrm{KBr}$ technique.

\subsection{Enzymatic activity assays}

Free and immobilized $\beta$-D-galactosidase hydrolytic activities were assayed using $o$-NPG $\left(30 \mathrm{mmol} \mathrm{L} \mathrm{L}^{-1}\right)$ as the substrate at $37^{\circ} \mathrm{C}$ in a thermostatic bath. The released $o$-nitrophenol was measured in a spectrophotometer at $415 \mathrm{~nm}$. Per definition one $\beta$-D-galactosidase activity unit $(\mathrm{U})$ is the quantity of enzyme required to convert $1 \mu \mathrm{mol}$ of the substrate per minute under the reaction conditions.

Free enzyme hydrolytic activity was measured by incubating the diluted enzyme solution $(50 \mu \mathrm{L})$ in the immobilization buffer $(270 \mu \mathrm{L})$ and $o$-NPG $(180 \mu \mathrm{L})$ for $2 \mathrm{~min}$. The reaction was halted with the addition of sodium carbonate buffer $\left(1.5 \mathrm{~mL}, 0.1 \mathrm{~mol} \mathrm{~L}^{-1}, \mathrm{pH} 10\right)$. For immobilized $\beta$-D-galactosidase, $10 \mathrm{mg}$ of the dried biocatalyst was incubated with an immobilization buffer $(1.62 \mathrm{~mL})$ and $o$-NPG $(1.08 \mathrm{~mL})$ for $30 \mathrm{~s}$ under continuous stirring. The reaction was halted with the addition of sodium carbonate buffer ( $\left.9 \mathrm{~mL}, 0.1 \mathrm{~mol} \mathrm{~L}^{-1}, \mathrm{pH} 10\right)$. All experiments were conducted in triplicate.

The immobilization parameters were determined according to the following equations (Sheldon \& van Pelt, 2013):

$$
\begin{aligned}
& \text { Immobilization yield }(\%)=\frac{\text { Immobilized activity }}{\text { Starting activity }} \times 100 \\
& \text { Efficiency }(\%)=\frac{\text { Observed activity }}{\text { Immobilized activity }} \times 100 \\
& \text { Activity recovery }(\%)=\frac{\text { Observed activity }}{\text { Starting activity }} \times 100
\end{aligned}
$$

2.5. Study of the effect of $p H$ on enzyme activity and study of thermal and storage stability of the biocatalysts

The optimal $\mathrm{pH}$ of free and immobilized $\beta$-D-galactosidase was acquired by measuring enzyme activity in different $\mathrm{pH}$ values of the phosphate buffer using $\mathrm{pH}$ values of 5.7, 6.0, 6.5, 7.0, 7.5 and 8.0 at $37{ }^{\circ} \mathrm{C}$. Tests were done in triplicate.

The thermal stability of free and immobilized $\beta$-D-galactosidase was assessed by incubating the biocatalyst in a thermostatic bath (40, 50, 60 and $70{ }^{\circ} \mathrm{C}$ ) in tubes with a phosphate buffer ( $\mathrm{pH}$ 6.5). After preset exposure times, the remaining enzyme activities were measured as described above in 2.4. Assays were made in triplicate.

In order to investigate the storage stability of the biocatalysts, they were stored in a phosphate buffer $(\mathrm{pH} 6.5)$ in the fridge at $4{ }^{\circ} \mathrm{C}$ for 30 days. Following the storage period, the biocatalysts were employed in the hydrolysis of $o$-NPG to determine remaining enzyme activities, as described in 2.4. Tests were done in duplicate every seven days.

\subsection{Determination of kinetic parameters}

The kinetic parameters, Michaelis-Menten constant $\left(\mathrm{K}_{\mathrm{M}}\right)$ and the maximum rate of reaction $\left(\mathrm{V}_{\max }\right)$ of free and immobilized enzymes were determined by a Lineweaver-Burk plot under optimal conditions, using increasing concentrations of $o$-NPG in solution, from $5 \mathrm{mmol} \mathrm{L}^{-1}$ to 50 mmol L ${ }^{-1}$ in the phosphate buffer ( $\mathrm{pH}$ 6.5). The $\mathrm{K}_{\mathrm{M}}$ and $\mathrm{V}_{\max }$ values were obtained from $\mathrm{a} \frac{1}{V} x \frac{1}{[S]}$ graph where $\mathrm{V}$ is the rate of reaction and $[\mathrm{S}]$ is the concentration of $o$-NPG. Using the linear regression of the LineweaverBurk plot $\frac{1}{V}=\frac{1}{V_{\max }}+\frac{K_{m}}{V_{\max }} \frac{1}{[S}$, which presents a slope of $\frac{K_{m}}{V_{\max }}$, intersecting the axis at $\frac{1}{V_{\max }}$.

\subsection{Operational stability}

The operational stabilities of the biocatalysts were evaluated by lactose hydrolysis in batch cycles. The experiment was carried out by incubating $10 \mathrm{mg}$ of each biocatalyst (SiTienz or SiTi-CHenz) in $1.0 \mathrm{~mL}$ aliquot of lactose solution $\left(50 \mathrm{~g} \mathrm{~L}^{-1}\right)$ in phosphate buffer ( $\mathrm{pH}$ 6.5). Each cycle was carried out at $37{ }^{\circ} \mathrm{C}$ for 60 min under stirring. At the end of each cycle, the biocatalysts were filtered, washed with the activity buffer and added to a fresh lactose solution. Samples of the hydrolyzed product were collected and analyzed enzymatically for glucose formation by the colorimetric method, without deproteinization (GOD-PAP), by enzymatic oxidation in the presence of glucose oxidase. Each collected aliquot of the hydrolyzed product was diluted 20 times in $\mathrm{NaCl}$ solution $\left(0.01 \mathrm{~mol} \mathrm{~L}^{-1}\right)$. The test was performed by mixing $10.0 \mu \mathrm{L}$ of the diluted product with $1.0 \mathrm{~mL}$ of the reagent, for $15 \mathrm{~min}$ at $37^{\circ} \mathrm{C}$. Afterwards, the absorbance was measured at $505 \mathrm{~nm}$. This experiment was performed in 
duplicate.

The operational stability was also evaluated with the use of a fixed bed reactor. This type of reactor consists of a glass cylindrical tube (diameter $=1 \mathrm{~cm}$; height $=5 \mathrm{~cm}$ ) filled with an immobile stack of biocatalyst particles ( $1 \mathrm{~g}$ of SiTi-CHenz), through which a substrate solution is pumped and converted into products, under temperature control $\left(37^{\circ} \mathrm{C}\right)$. The substrate was a $50 \mathrm{~g} \mathrm{~L}^{-1}$ lactose solution diluted in phosphate buffer (pH 6.5). Flow rate was maintained at $0.3 \mathrm{~mL} \mathrm{~min}^{-1}$ using a peristaltic pump Watson Marlow 120U. Samples of the hydrolyzed product were collected in triplicate after preset times and analyzed enzymatically for glucose formation as described above.

\subsection{Statistical analysis}

Experiments were carried out in triplicate, using three independent samples. Statistical analysis was conducted using Past statistical software (freeware from Oyvind Hammer v. 4.03). The results were expressed as "mean \pm standard deviation" (as " $\mathrm{X} \pm \mathrm{SD}$ ") of three determinations. The analysis of variance (ANOVA) and distinction between the mean values of the different treatments was evaluated using Tukey's test $(\rho \leq 0.05)$.

\section{Results and discussion}

\subsection{Structural and textural characterization}

The microanalysis results obtained on several areas of the pressed powder pellets found $75.9 \mathrm{wt} \% \mathrm{SiO}_{2}( \pm 1.4 \mathrm{wt} \%)$ and $24.1 \mathrm{wt} \% \mathrm{TiO}_{2}$ $( \pm 1.4 \mathrm{wt} \%)$, compatible with the planned three to one ratio of the oxides. A SEM image of one of the analysis regions and a representative $\mathrm{X}$ ray spectrum showing the characteristic peaks of $\mathrm{Ti}, \mathrm{Si}$, and $\mathrm{O}$ are shown in Fig. S2, Supplementary Material. The organic content of the samples was determined by TGA, which is more appropriate for the determination of the organic fraction in hybrid materials, and the results are presented in Fig. S3, Supplementary Material. The weight loss from room temperature to $150{ }^{\circ} \mathrm{C}$ was attributed to water desorption. In the range from $150{ }^{\circ} \mathrm{C}$ to $650{ }^{\circ} \mathrm{C}$, the weight loss can be related to the dehydroxylation reactions of silica/titania and organic moiety decomposition. Based on the weight loss values, the organic content incorporated after successive modifications was estimated and it is shown in Table 1. Comparing the relevant temperature range between $150^{\circ} \mathrm{C}$ and $650{ }^{\circ} \mathrm{C}$ in the TGA curves, it can be seen that the weight loss increased after the incorporation of chitosan: for SiTi the loss was of $2.22 \%$ and for SiTi-CH of 7.34\%, allowing the conclusion that the $5 \%$ difference was due to the loss of incorporated chitosan. After further modifications of $\mathrm{SiTi}-\mathrm{CH}$, an additional weight loss of $0.87 \%$ showed the loss of incorporated glutaraldehyde and the weight loss of $2.32 \%$ indicated the loss of the successfully incorporated enzyme (Table 1 ).

Fig. $1 \mathrm{a}$ and $1 \mathrm{~b}$ show the high-resolution SEM images of the SiTi and SiTi-CH supports. Fig. 1a shows a representative image of SiTi obtained by the sol-gel method, where the xerogel is formed by agglomerates of nanometric primary particles. Compared to SiTi in Fig. 1a, no significant

\section{Table 1}

Weight losses obtained by TGA in different ranges of temperature and estimated organic content incorporated in each step.

\begin{tabular}{|c|c|c|c|c|}
\hline \multirow[t]{2}{*}{ Samples } & \multirow[t]{2}{*}{$0-150^{\circ} \mathrm{C}(\%)$} & \multirow[t]{2}{*}{$150-650^{\circ} \mathrm{C}(\%)$} & \multicolumn{2}{|c|}{ Organic content (\%) } \\
\hline & & & Total & For each step \\
\hline SiTi & $1.24( \pm 0.01)$ & $2.22( \pm 0.02)$ & - & - \\
\hline SiTi-CH & $2.51( \pm 0.02)$ & $7.34( \pm 0.05)$ & $\begin{array}{l}5.12 \\
( \pm 0.05)\end{array}$ & $5.12( \pm 0.05)$ \\
\hline $\begin{array}{l}\text { SiTi- } \\
\text { CHglut }\end{array}$ & $1.63( \pm 0.01)$ & $8.21( \pm 0.05)$ & $\begin{array}{l}5.99 \\
( \pm 0.05)\end{array}$ & $0.87( \pm 0.01)$ \\
\hline SiTi-CHenz & $3.54( \pm 0.03)$ & $10.53( \pm 0.05)$ & $\begin{array}{l}8.31 \\
( \pm 0.05)\end{array}$ & $2.32( \pm 0.05)$ \\
\hline
\end{tabular}
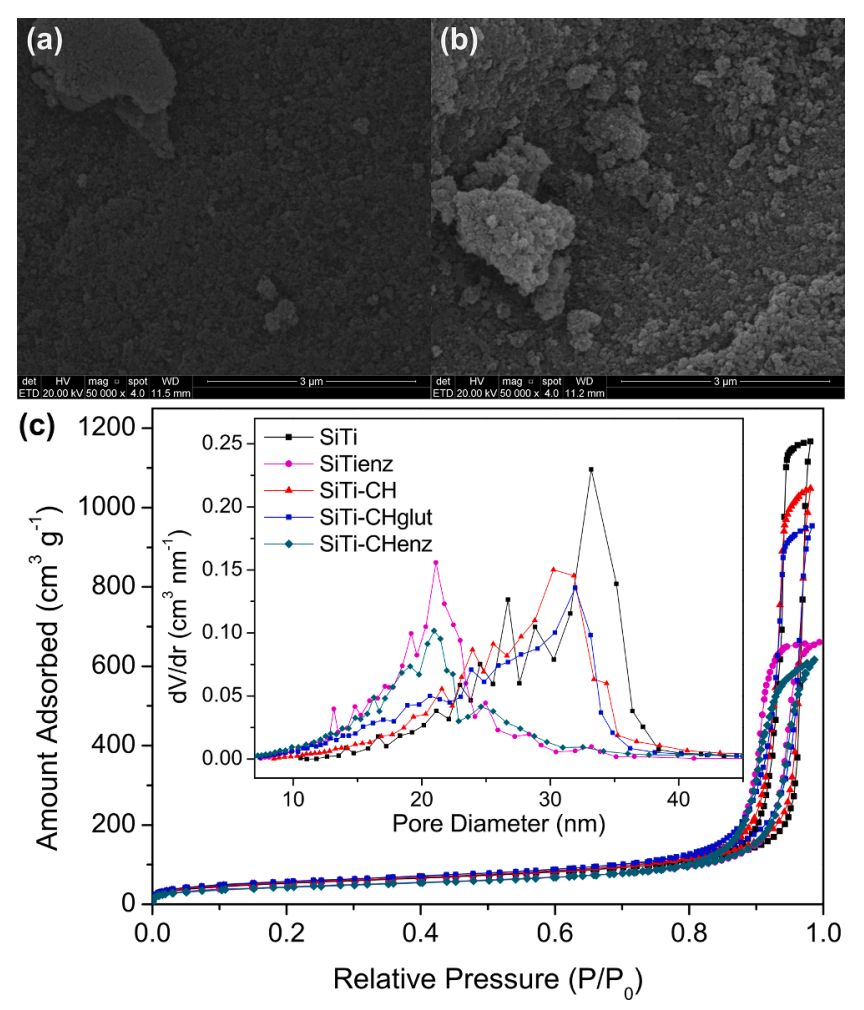

Fig. 1. (a) SEM image of the support SiTi, (b) SEM image of the support SiTi$\mathrm{CH}$ and (c) $\mathrm{N}_{2}$ adsorption-desorption isotherms and pore-size distribution curves (Inset Fig. 1(c)): SiTi, SiTienz, SiTi-CH, SiTi-CHglut and SiTiCHenz samples.

morphological differences were observed in SiTi-CH, after chitosan coating (Fig. 1b).

Fig. 1c shows the $\mathrm{N}_{2}$ adsorption/desorption isotherms of SiTi, SiTienz, SiTi-CH, SiTi-CHglut and SiTi-CHenz. All are type IV isotherms (Gregg \& Sing, 1982), characteristic of mesoporous materials. After surface modifications and enzyme immobilization the isotherms showed a decrease of the amount of adsorbed nitrogen. Pore size distribution curves are presented as an inset of Fig. 1c, showing a maximum pore size of approximately $35 \mathrm{~nm}$ for the support. After the addition of chitosan and glutaraldehyde, a reduction of maximum pore size to $30 \mathrm{~nm}$ was observed, evidencing that the organics covered the inner pore surface. The pore size presented by the support, with and without modifications, is compatible with the enzyme tetramer size, estimated as $15.1 \mathrm{~nm} \times$ $17.1 \mathrm{~nm} \times 10.7 \mathrm{~nm}$ (Pavel et al., 2017), thereby allowing the immobilization, after which the pore size maximum shifts to approximately 20 $\mathrm{nm}$. In both biocatalysts, SiTi-CHenz and SiTienz, the direct enzyme immobilization occurred in these same pore regions and resulted in a similar curve, showing that both systems promote a very good dispersion of the enzyme on the surface of the supports.

Table 2 shows details of the textural properties of the materials. The modification of SiTi support with chitosan, glutaraldehyde, and enzyme immobilization, caused a decrease in the amount of $\mathrm{N}_{2}$ adsorbed and, as a result, there was a decrease of pore volume from $1.79 \mathrm{~cm}^{3} \mathrm{~g}^{-1}$ for SiTi,

Table 2

BET surface area and pore volume results.

\begin{tabular}{lll}
\hline Sample & $\mathrm{S}_{\mathrm{BET}}\left(\mathrm{m}^{2} \mathrm{~g}^{-1}\right)$ & Pore Volume $\left(\mathrm{cm}^{3} \mathrm{~g}^{-1}\right)$ \\
\hline SiTi & $190( \pm 8)$ & $1.79( \pm 0.05)$ \\
SiTienz & $155( \pm 6)$ & $1.02( \pm 0.04)$ \\
SiTi-CH & $195( \pm 8)$ & $1.61( \pm 0.05)$ \\
SiTi-CHglut & $204( \pm 8)$ & $1.46( \pm 0.04)$ \\
SiTi-CHenz & $153( \pm 6)$ & $0.94( \pm 0.04)$ \\
\hline
\end{tabular}


to $0.94 \mathrm{~cm}^{3} \mathrm{~g}^{-1}$ for SiTi-CHenz, and to $1.02 \mathrm{~cm}^{3} \mathrm{~g}^{-1}$ for SiTienz. The specific surface area remained constant (within experimental error) after modifications with chitosan and glutaraldehyde (around $190 \mathrm{~m}^{2}$ $\mathrm{g}^{-1}$ ) and decreased after the enzyme immobilization to $155 \mathrm{~m}^{2} \mathrm{~g}^{-1}$ for SiTienz and to $153 \mathrm{~m}^{2} \mathrm{~g}^{-1}$ for SiTi-CHenz. This allows us to infer that chitosan and glutaraldehyde cover the surface of the pores as a nanometric coating, leaving the pore volume almost unchanged. This is very important for the immobilization of the enzyme inside the pores, because it promotes the availability of active sites and consequent enzyme stability. The marked textural changes occurred only after the addition of the enzyme, indicating that the enzymes were in fact immobilized inside the mesopores. Additionally, the pore size of $20 \mathrm{~nm}$ and pore volumes of $1.02 \mathrm{~cm}^{3} \mathrm{~g}^{-1}$ (SiTienz) and $0.94 \mathrm{~cm}^{3} \mathrm{~g}^{-1}$ (SiTi$\mathrm{CHenz}$, which are maintained after enzyme immobilization, are very suitable for substrate access and enhanced enzyme activity (Sigurdardóttir et al., 2018).

Fig. 2a shows the XRD patterns of the SiTi and the SiTi-CH supports. In the XRD pattern of SiTi, a typical halo of amorphous material is observed near $20^{\circ}$, and an incipient crystallization of titania in anatase structure can be seen. These features were not modified by the chitosan coating, as expected, considering that the coating is very thin and all surface modifications were performed at ambient temperature.

Fig. $2 \mathrm{~b}$ shows the infrared spectra of SiTi, SiTi-CH, SiTi-CHglut and SiTi-CHenz samples. The wide band at $3300 \mathrm{~cm}^{-1}$ was ascribed to the O$\mathrm{H}$ stretching mode of silanol groups (Si-OH). The band at $2950 \mathrm{~cm}^{-1}$ appeared after the incorporation of chitosan in the material and was attributed to the $\mathrm{C}-\mathrm{H}$ stretch. The bands corresponding to silica tetrahedral harmonic vibration are located at 1995 and $1880 \mathrm{~cm}^{-1}$ (Costa, Gallas, Benvenutti, \& Jornada, 1997). The band at $1633 \mathrm{~cm}^{-1}$ was assigned to the angular deformation of adsorbed water. In the spectrum of the SiTi-CHenz sample, this band appears larger indicating the presence of $\mathrm{C}=\mathrm{O}$ stretching of the enzyme. The band at $1550 \mathrm{~cm}^{-1}$ is due to the symmetric angular deformation of $-\mathrm{NH}_{2}$ of the chitosan, confirming the incorporation of chitosan in the material. This band suffered a slight decrease in intensity after the incorporation of glutaraldehyde due to the interaction of the amino with the aldehyde groups. The band with a maximum at $1100 \mathrm{~cm}^{-1}$ was assigned to the combination of silica network vibrations (Si-O-Si). The band at $930 \mathrm{~cm}^{-1}$ in the SiTi sample was attributed to the $\mathrm{Si}-\mathrm{O}$ stretch of silicon not bridged to another silicon, i.e., $\mathrm{Si}-\mathrm{OH}$ and $\mathrm{Si}-\mathrm{O}$ stretching vibrations of $\mathrm{Si}-\mathrm{O}-\mathrm{Ti}$ bonds so demonstrating the connection of the silica and titania phases. The shoulder at $970 \mathrm{~cm}^{-1}$ is due to the Ti-O stretching of TiOH. The relative change of these bands, after the incorporation of glutaraldehyde and enzyme immobilization, can indicate an interaction of the Ti-OH groups with the aldehyde groups or $\mathrm{CO}$ groups of the enzyme, and $\mathrm{H}$ interaction of Si-OH groups with $\mathrm{NH}_{2}$ enzyme. The $800 \mathrm{~cm}^{-1}$ band corresponds to

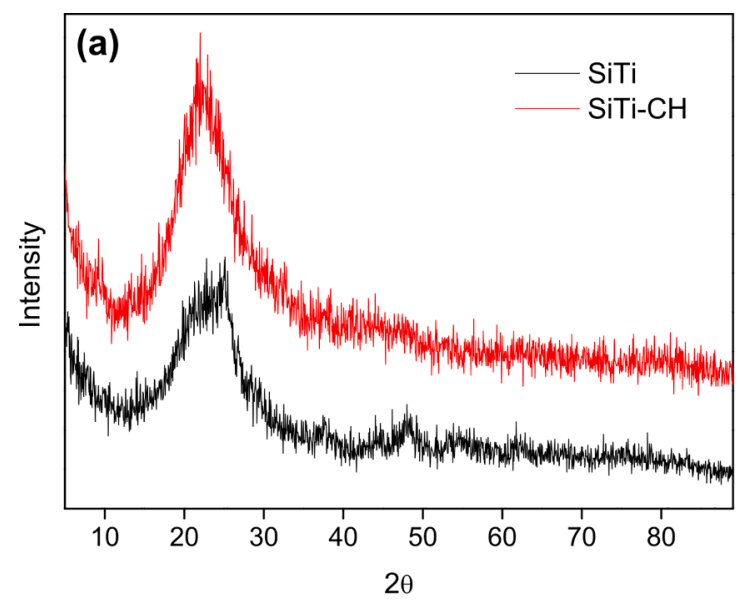

vibrations of the silica tetrahedra. Other bands that could prove the bond Ti-O-C and the presence of glycosidic rings are in the region between 1000 and $1150 \mathrm{~cm}^{-1}$ and are possibly masked by the silica bands, considering that more than $70 \%$ of the sample consists of silica (AnayaEsparza et al., 2020).

\subsection{Immobilization parameters}

The prepared materials were used as supports for $\beta$-D-galactosidase immobilization and the results of enzyme activity, immobilization yield, efficiency, and activity recovery, are shown on Table 3. The SiTi-CHenz biocatalyst showed higher $(73 \pm 1) \%$ values of immobilization yield if compared to the SiTienz biocatalyst $(40 \pm 1) \%(\rho<0.05)$, thus indicating that a large part of the enzyme offered to the SiTi matrix did not remain attached to the support. Even so, the immobilization parameters presented by this biocatalyst were quite appreciable since the enzyme can link directly to the support via the acidic sites in titania without the need of support surface functionalization. The amount of protein immobilized on the support, determined by the Lowry method, was ( $9 \pm$ 1) $\mu \mathrm{g} \mathrm{mg}{ }^{-1}$, for SiTi-CHenz and $(5 \pm 1) \mu g \mathrm{mg}^{-1}$, for SiTienz. The biocatalyst containing chitosan (SiTi-CHenz) showed the highest observed activity per gram of support $(1223 \pm 45) \mathrm{U} \mathrm{g}^{-1}$, efficiency $(74 \pm 1) \%$, and activity recovery $(54 \pm 2) \%(\rho<0.05)$. The obtained process parameters indicated that the chitosan coating increased the enzyme molecules retention capacity (immobilization yield) and assisted in the maintenance of the enzymatic activity of the immobilized protein (immobilization efficiency), offering a favorable microenvironment to maintain the enzyme catalytic capacity and, consequently, increasing the recovered activity and contributing to a greater observed activity per gram of support.

Improvements in the stability of enzymes, when attached to chitosan supports, have been observed in previous works (de Albuquerque et al., 2018; Duarte et al., 2017; Flores et al., 2019; Klein et al., 2012; Urrutia et al., 2018). In general, the authors agree that the protection provided by the $3 \mathrm{D}$ structure formed between the enzyme and chitosan is responsible for the increase in stability of the immobilized enzyme in comparison with the free enzyme. At the $\mathrm{pH}$ conditions used in this work, it is generally assumed that the enzyme binds to the support at a single point, which is the amino terminal of the protein (Barbosa et al., 2014). However, in addition to weak multipoint interactions that could be established between chitosan and the enzyme, some authors speculate that there might be multipoint covalent bonds, even at low $\mathrm{pH}$ values (Barbosa et al., 2014; Duarte et al., 2017; Flores et al., 2019; Schöffer et al., 2017). These suggestions are based on the evidence that the pKa of amino acids are strongly influenced by the microenvironment. Therefore, the pKa of an amino acid such as Lysine can vary from

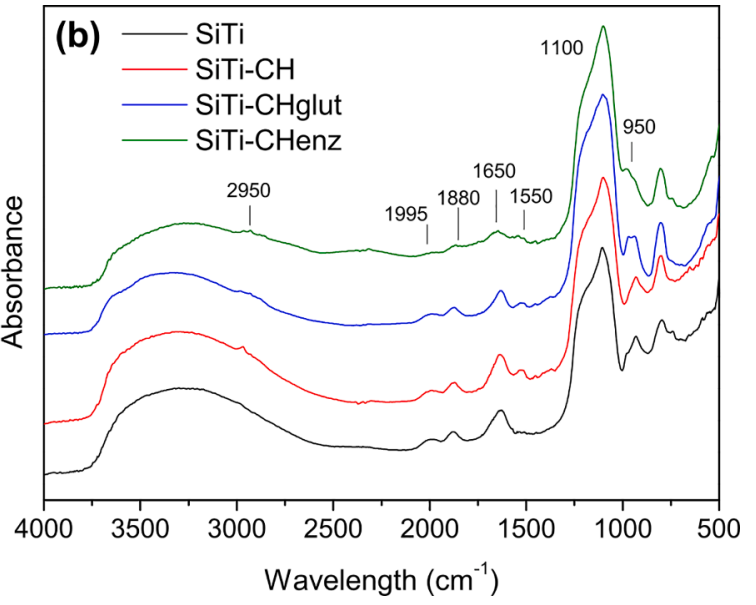

Fig. 2. (a) XRD of the supports SiTi and SiTi-CH. (b) Infrared spectra obtained at room temperature for SiTi, SiTi-CH, SiTi-CHglut and SiTi-CHenz. 
Table 3

Immobilization process parameters of SiTienz and SiTi-CHenz samples.

\begin{tabular}{|c|c|c|c|c|c|}
\hline Sample & Protein concentration ( $\mu \mathrm{g} \mathrm{mg}^{-1}$ of support) & Observed Activity $\left(\mathrm{U} \mathrm{g}^{-1}\right)$ & Immobilization Yield (\%) & Efficiency (\%) & Activity Recovery (\%) \\
\hline SiTienz & $5( \pm 1)$ & $711( \pm 24)^{\mathrm{a}}$ & $40( \pm 1)^{\mathrm{a}}$ & $53( \pm 1)^{\mathrm{a}}$ & $21( \pm 2)^{\mathrm{a}}$ \\
\hline SiTi-CHenz & $9( \pm 1)$ & $1223( \pm 45)^{\mathrm{b}}$ & $73( \pm 1)^{\mathrm{b}}$ & $74( \pm 1)^{\mathrm{b}}$ & $54( \pm 2)^{\mathrm{b}}$ \\
\hline
\end{tabular}

Any two means in the same column followed by the same letter are not significantly $(\rho \leq 0.05)$ different according to Tukey test.

5.3 to 10.4 according to the region of the residue (Isom, Castañed, Cannon, \& García-Moreno, 2011). Thus, even if a small percentage of deprotonated amines (protein surface lysins) is present at a lower $\mathrm{pH}$, this would be sufficient to allow the reaction with glutaraldehyde previously bound to chitosan, forming multipoint connections (Migneault, Dartiguenave, Bertrand, \& Waldron, 2004), increasing the rigidity of the protein structure and strengthening the connection between the enzyme molecule and the support. From a practical point of view, this is important because it allows the use of biocatalysts in batch repetitions or in continuous flow reactors without the leaching of enzyme molecules during the operation.

\subsection{Study of the effect of pH on enzyme activity and study of thermal and storage stability of the biocatalysts}

The influence of $\mathrm{pH}$ on relative activities of both free and immobilized enzymes was analyzed in the range of 5.7 and 8.0 (Fig. S4, Supplementary Material). The biocatalysts showed the maximum value of relative activity at $\mathrm{pH} 6.5$. With respect to $\mathrm{pH}$ values above 6.5 , the SiTiCHenz biocatalyst showed slightly higher activity than those of the free enzyme and SiTienz, keeping the value of $(45 \pm 1) \%$ at $\mathrm{pH} 8.0$, while the free form and the SiTienz were near $(30 \pm 3) \%$.

The thermal stabilities of free and immobilized enzymes are presented in Fig. S5, Supplementary Material. In experiments performed at $40{ }^{\circ} \mathrm{C}$ (Fig. S5a, Supplementary Material), SiTienz and SiTi-CHenz biocatalysts showed lower decay of relative activity over time when compared with the free enzyme. After $24 \mathrm{~h}$ of $40{ }^{\circ} \mathrm{C}$ incubation, SiTienz retained $(40 \pm 4) \%$ of the initial activity, while SiTi-CHenz maintained $(30 \pm 2) \%$ and the free enzyme $(20 \pm 5) \%$. After $24 \mathrm{~h}$ of incubations at $50{ }^{\circ} \mathrm{C}, 60{ }^{\circ} \mathrm{C}$, and $70{ }^{\circ} \mathrm{C}$ (Figs. 5b, $5 \mathrm{c}$ and $5 \mathrm{~d}$, Supplementary Material) both free and immobilized enzymes tended to a total loss of relative activity.

Although the relative activity of the immobilized enzyme does not show marked improvements in more acidic and alkaline $\mathrm{pH}$, nor does it present a better thermal stability; the immobilization process maintains the basic properties of the enzyme, with similar behavior as the free enzyme. This consistency of properties in relation to optimum $\mathrm{pH}$ and thermal stability of the immobilized $\beta$-D-galactosidase was found by Ricardi et al. (2018), when the enzyme was immobilized in a silica/ chitosan composite.

The Fig. S6, Supplementary Material, shows the enzymatic activity of the biocatalysts, measured every seven days, aiming to evaluate the storage stability of free and immobilized enzymes. The enzymatic activity was maintained near $90 \%$ for five weeks under storage.

\subsection{Determination of kinetic parameters}

The kinetic parameters, Michaelis-Menten constant $\left(\mathrm{K}_{\mathrm{M}}\right)$ and the maximum rate of reaction $\left(\mathrm{V}_{\max }\right)$ of free and immobilized enzyme were obtained varying the substrate concentration of $o$-NPG in solution. Fig. S7, Supplementary Material, shows the Lineweaver-Burk plot and linear regression line of free and immobilized enzyme. The linear regression equation is $\frac{1}{V}=0.0004 \frac{1}{[S]}+0.0535$ for free enzyme, and $\frac{1}{V}=$ $9.10^{-6} \frac{1}{|S|}+0.0011$ for SiTi-CHenz. The values obtained for $\mathrm{K}_{\mathrm{M}}$ were 7.48 $\mu \mathrm{mol} \mathrm{mL} \mathrm{m}^{-1}$ for free enzyme and $8.18 \mu \mathrm{mol} \mathrm{mL}^{-1}$ for SiTi-CHenz. For $\mathrm{V}_{\max }$, the values obtained were $149.52 \mu \mathrm{mol} \mathrm{min} \mathrm{mg}^{-1} \mathrm{mg}^{-1}$ of protein for free enzyme and $99.63 \mu \mathrm{mol} \mathrm{min}^{-1} \mathrm{mg}^{-1}$ of protein for SiTi-CHenz. The
$\mathrm{V}_{\max }$ value slightly decreased when the enzyme was immobilized and the $K_{M}$ value showed a small increase. This result is important because the SiTiCHenz biocatalyst presented an enzyme/substrate affinity very similar to the free enzyme.

\subsection{Operational stability}

The biocatalysts were evaluated for their operational stability using batch and fixed bed reactors, as previously described. Results are shown in Fig. 3.

The operational stability of immobilized enzymes (SiTienz and SiTiCHenz) was evaluated under repeated batch reactions for the hydrolysis of lactose. After the first cycle, shown in Fig. 3a, the SiTienz biocatalyst achieved $(85 \pm 5) \%$ conversion of lactose hydrolysis, while SiTi-CHenz reached $(100 \pm 12) \%$. The highest relative activity loss after the first hydrolysis cycle observed for SiTienz can be attributed to the existence of covalent as well as weak enzyme-silica/titania surface interactions, which lead to partial enzyme leaching. This leaching suggests the existence of non-covalent type interactions, such as weak physical enzyme adsorption, that can be favored by the enzyme entrapment into the pores (Ghannadi, Abdizadeh, Miroliaei, \& Saboury, 2019; Prazeres et al., 2019). These conversion values were considered as $100 \%$ of the relative activity. As seen in Fig. 3a, the relative activity of SiTienz decreased to $(70 \pm 5) \%$ after the second cycle, retaining only $(23 \pm 6) \%$ of the relative activity after 15 cycles, showing lower operational stability. In contrast, the relative hydrolytic activity of the biocatalyst containing chitosan (SiTi-CHenz) remained close to $(100 \pm 10) \%$ after 15 cycles of lactose hydrolysis. In the SiTi-CHenz biocatalyst, the enzyme remained attached to the support without changing its active sites throughout the 15 hydrolysis cycles, and without a considerable loss of relative activity.

The operational stability of the biocatalyst SiTi-CHenz was also evaluated in a fixed bed reactor for the lactose hydrolysis reaction. In Fig. 3b, it can be seen that the biocatalyst SiTi-CHenz maintained its hydrolytic activity close to $(100 \pm 10) \%$ after 14 days of continuous operation of the reactor. The hydrolytic conversion rate of lactose, forming glucose and galactose, was $(85 \pm 4) \%$. This conversion percentage can probably be increased by optimizing the reactor conditions, such as increasing the reactor column volume, increasing the concentration of immobilized enzyme, and enlarging the substrate residence time of the lactose in the reactor. However, our reactor experiment demonstrated the feasibility of using our biocatalyst in continuous processes.

\section{Conclusion}

Silica/titania-based mesoporous powders, modified with chitosan and glutaraldehyde, were prepared and applied for the first time to the immobilization of $\beta$-D-galactosidase from Kluyveromyces lactis. The organic components chitosan and glutaraldehyde were gradually incorporated on the surface, inside of the pores of the SiTi matrix, in a nanometric dispersion level. The enzyme was immobilized in these coated pores, and the obtained biocatalyst showed a very suitable texture for enzymatic catalysis, presenting a pore size distribution maximum around $20 \mathrm{~nm}$ and a surface area of $153 \mathrm{~m}^{2} \mathrm{~g}^{-1}$. These characteristics allowed its high performance as a biocatalyst, resulting in high activity $\left(1223 \mathrm{U} \mathrm{g}^{-1}\right)$ and excellent operational stability. Particularly the SiTi-CHenz biocatalyst showed excellent stability without significant loss of enzymatic activity after 15 batch cycles of lactose 

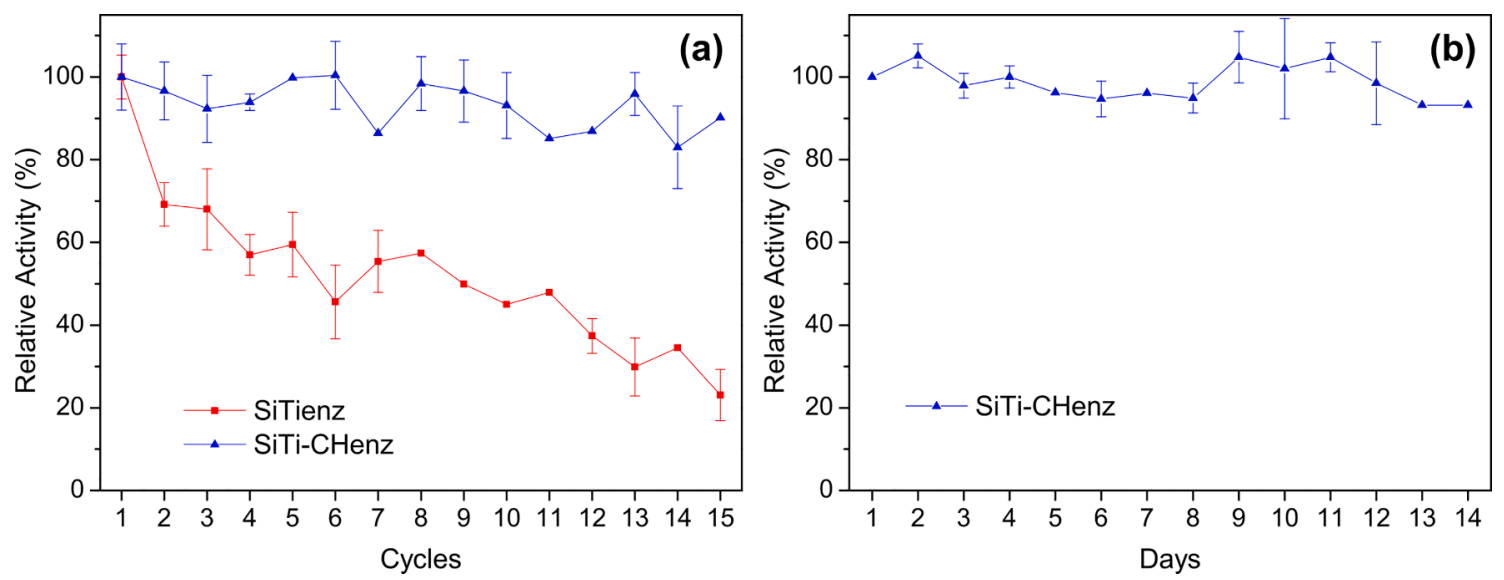

Fig. 3. Operational stability of the immobilized enzyme, (a) in a batch reactor and (b) in a fixed bed reactor, at $37{ }^{\circ} \mathrm{C}$ and $\mathrm{pH} 6.5$.

hydrolysis and after 14-day operation in a continuous flow reactor.

In conclusion, the incorporation of chitosan to a large extent in a porous mixed oxide support was determinant in improving the physicochemical properties of the biocatalyst. The design of composition and pore texture of the inorganic matrix, as well as the synthesis of the final composite support, were fundamental steps in the development of this biocatalyst, promoting catalytic activity and operational stability of the enzyme. The porous silica/titania/chitosan hybrid material proposed in this work has the potential to be applied as support for other enzymes, in the development of other hybrid biocatalysts for the food industry.

\section{CRediT authorship contribution statement}

Natália Carminatti Ricardi: Conceptualization, Investigation, Validation, Formal analysis, Writing - original draft, Writing - review \& editing, Visualization. Leliz Ticona Arenas: Conceptualization, Writing - original draft, Writing - review \& editing, Visualization, Resources, Methodology. Edilson Valmir Benvenutti: Investigation, Resources, Writing - review \& editing, Visualization, Funding acquisition, Methodology. Ruth Hinrichs: Investigation, Methodology, Validation, Resources. Elí Emanuel Esparza Flores: Investigation, Validation, Formal analysis. Plinho Francisco Hertz: Conceptualization, Resources, Writing - review \& editing, Visualization, Funding acquisition, Methodology, Project administration. Tania Maria Haas Costa: Conceptualization, Writing - original draft, Writing - review \& editing, Resources, Project administration, Supervision, Funding acquisition.

\section{Declaration of Competing Interest}

The authors declare that they have no known competing financial interests or personal relationships that could have appeared to influence the work reported in this paper.

\section{Acknowledgments}

This research was fomented by the Conselho Nacional de Desenvolvimento Científico e Tecnológico (CNPq), Fundação de Amparo à Pesquisa do Estado do Rio Grande do Sul (FAPERGS) and Coordenação de Aperfeiçoamento de Pessoal de Nível Superior (CAPES). We also thank the Brazilian government for the scholarships and grants.

\section{Appendix A. Supplementary data}

Supplementary data to this article can be found online at https://doi. org/10.1016/j.foodchem.2021.129890.

\section{References}

Anaya-Esparza, L. M., Ruvalcaba-Gómez, J. M., Maytorena-Verdugo, C. I., González Silva, N., Romero-Toledo, R., Aguilera-Aguirre, S., ... Montalvo-González, E. (2020). Chitosan-TiO2: A versatile hybrid composite. Materials, 13(4), 1-27. https://doi.org/ 10.3390/ma13040811.

Banjanac, K., Carević, M., Ćorović, M., Milivojević, A., Prlainović, N., Marinković, A., \& Bezbradica, D. (2016). Novel $\beta$-galactosidase nanobiocatalyst systems for application in the synthesis of bioactive galactosides. RSC Advances, 6, 97216-97225. https:// doi.org/10.1039/c6ra20409k.

Barbosa, O., Ortiz, C., Berenguer-Murcia, Á., Torres, R., Rodrigues, R. C., \& FernandezLafuente, R. (2014). Glutaraldehyde in bio-catalysts design: A useful crosslinker and a versatile tool in enzyme immobilization. RSC Advances, 4(4), 1583-1600. https:// doi.org/10.1039/c3ra45991h.

Bilal, M., \& Iqbal, H. M. N. (2019). Naturally-derived biopolymers: Potential platforms for enzyme immobilization. International Journal of Biological Macromolecules, 130, 462-482. https://doi.org/10.1016/j.ijbiomac.2019.02.152.

Bilal, M., Iqbal, H. M. N., Guo, S., Hu, H., Wang, W., \& Zhang, X. (2018). State-of-the-art protein engineering approaches using biological macromolecules: A review from immobilization to implementation view point. International Journal of Biological Macromolecules, 108, 893-901. https://doi.org/10.1016/j.ijbiomac.2017.10.182.

Bolivar, J. M., Consolati, T., Mayr, T., \& Nidetzky, B. (2013). Shine a light on immobilized enzymes: Real-time sensing in solid supported biocatalysts. Trends in Biotechnology, 31, 196-205. https://doi.org/10.1016/j.tibtech.2013.01.004.

Chapman, J., Ismail, A. E., \& Dinu, C. Z. (2018). Industrial applications of enzymes: Recent advances, techniques, and outlooks. Catalysts, 8, 238-264. https://doi.org/ $10.3390 /$ catal8060238.

Costa, T. M. H., Gallas, M. R., Benvenutti, E. V., \& Jornada, J. A. H. da (1997). Infrared and thermogravimetric study of high pressure consolidation in alkoxide silica gel powders. Journal of Non-Crystalline Solids, 220(2-3), 195-201. https://doi.org/ 10.1016/S0022-3093(97)00236-6.

de Albuquerque, T. L., Gomes, S. D. L., D’Almeida, A. P., Fernandez-Lafuente, R., Gonçalves, L. R. B., \& Rocha, M. V. P. (2018). Immobilization of $\beta$-galactosidase in glutaraldehyde-chitosan and its application to the synthesis of lactulose using cheese whey as feedstock. Process Biochemistry, 73, 65-73. https://doi.org/10.1016/j. procbio.2018.08.010.

Duarte, L. S., Schöffer, J.d. N., Lorenzoni, A. S. G., Rodrigues, R. C., Rodrigues, E., \& Hertz, P. F. (2017). A new bioprocess for the production of prebiotic lactosucrose by an immobilized $\beta$-galactosidase. Process Biochemistry, 55, 96-103. https://doi.org/ 10.1016/j.procbio.2017.01.015.

El Kadib, A., \& Bousmina, M. (2012). Chitosan bio-based organic-inorganic hybrid aerogel microspheres. Chemistry A European Journal, 18(27), 8264-8277. https:// doi.org/10.1002/chem.201104006.

Kadib, A. E., Molvinger, K., Guimon, C., Quignard, F., \& Brunel, D. (2008). Design of stable nanoporous hybrid chitosan/titania as cooperative bifunctional catalysts. Chemistry of Materials, 20(6), 2198-2204. https://doi.org/10.1021/cm800080s.

Flores, E. E. E., Cardoso, F. D., Siqueira, L. B., Ricardi, N. C., Costa, T. H., Rodrigues, R. C., Klein, M. P., ... Hertz, P. F. (2019). Influence of reaction parameters in the polymerization between genipin and chitosan for enzyme immobilization. Process Biochemistry, 84, 73-80. https://doi.org/10.1016/j.procbio.2019.06.001.

Garcia-Galan, C., Berenguer-Murcia, Á., Fernandez-Lafuente, R., \& Rodrigues, R. C. (2011). Potential of different enzyme immobilization strategies to improve enzyme performance. Advanced Synthesis \& Catalysis, 353(16), 2885-2904. https://doi.org/ 10.1002/adsc. 201100534.

Ghannadi, S., Abdizadeh, H., Miroliaei, M., \& Saboury, A. A. (2019). Immobilization of alcohol dehydrogenase on titania nanoparticles to enhance enzyme stability and remove substrate inhibition in the reaction of formaldehyde to methanol. Industrial and Engineering Chemistry Research, 58(23), 9844-9854. https://doi.org/10.1021/ acs.iecr. $9 \mathrm{~b} 01370$.

Gregg, S. J., \& Sing, K. S. W. (1982). Adsorption, surface area and porosity (2nd ed.). London: Academic Press. 
Grosová, Z., Rosenberg, M., \& Rebroš, M. (2008). Perspectives and applications of immobilised $\beta$-galactosidase in food industry - A review. Czech Journal of Food Sciences, 26, 1-14. https://doi.org/10.17221/1134-CJFS.

Isom, D. G., Castaneda, C. A., Cannon, B. R., \& Garcia-Moreno, B. E. (2011). Large shifts in pKa values of lysine residues buried inside a protein. Proceedings of the National Academy of Sciences, 108(13), 5260-5265. https://doi.org/10.1073/ pnas. 1010750108.

Klein, M. P., Nunes, M. R., Rodrigues, R. C., Benvenutti, E. V., Costa, T. M. H., Hertz, P. F., \& Ninow, J. L. (2012). Effect of the support size on the properties of $\beta$-galactosidase immobilized on chitosan: Advantages and disadvantages of macro and nanoparticles. Biomacromolecules, 13(8), 2456-2464. https://doi.org/10.1021/ bm3006984.

Krajewska, B. (2004). Application of chitin- and chitosan-based materials for enzyme immobilizations: A review. Enzyme and Microbial Technology, 35(2-3), 126-139. https://doi.org/10.1016/j.enzmictec.2003.12.013.

Laranjo, M. T., Morawski, F. M., Dias, S. L. P., Benvenutti, E. V., Arenas, L. T., \& Costa, T. M. H. (2019). Silica/titania graphite composite modified with chitosan and tyrosinase employed as a sensitive biosensor for phenolic compounds. Journal of the Brazilian Chemical Society, 30(12), 2660-2671. https://doi.org/10.21577/01035053.20190190.

Li, H., Cao, Y., Li, S., Jiang, Y., Chen, J., \& Wu, Z. (2019). Optimization of a dualfunctional biocatalytic system for continuous hydrolysis of lactose in milk. Journal of Bioscience and Bioengineering, 127(1), 38-44. https://doi.org/10.1016/j. jbiosc.2018.07.009.

Madhavan, A., Sindhu, R., Binod, P., Sukumaran, R. K., \& Pandey, A. (2017). Strategies for design of improved biocatalysts for industrial applications. Bioresource Technology, 245, 1304-1313. https://doi.org/10.1016/j.biortech.2017.05.031.

Migneault, I., Dartiguenave, C., Bertrand, M. J., \& Waldron, K. C. (2004). Glutaraldehyde: Behavior in aqueous solution, reaction with proteins, and application to enzyme crosslinking. BioTechniques, 37(5), 790-802. https://doi.org/ 10.2144/04375RV01.

Morawski, F.d. M., Deon, M., Nicolodi, S., de Menezes, E. W., Costa, T. M. H., Dias, S. L. P., Benvenutti, E. V., \& Arenas, L. T. (2018). Magnetic silica/titania xerogel applied as electrochemical biosensor for catechol and catecholamines. Electrochimica Acta, 264, 319-328. https://doi.org/10.1016/j. electacta.2018.01.127.

Pavel, I.-A., Prazeres, S. F., Montalvo, G., García Ruiz, C., Nicolas, V., Celzard, A., .. Pasc, A. (2017). Effect of meso vs macro size of hierarchical porous silica on the adsorption and activity of immobilized $\beta$-galactosidase. Langmuir, 33(13), 3333-3340. https://doi.org/10.1021/acs.langmuir.7b00134.

Prazeres, S. F., Zapata, F., Canilho, N., Pasc, A., García-Ruiz, C., \& Montalvo, G. (2019) Probing the confinement of $\beta$-galactosidase into meso-macro porous silica by Raman spectroscopy. Microporous and Mesoporous Materials, 278, 149-155. https://doi.org/ 10.1016/j.micromeso.2018.11.032.

Ricardi, N. C., de Menezes, E. W., Valmir Benvenutti, E., da Natividade Schöffer, J., Hackenhaar, C. R., Hertz, P. F., \& Costa, T. M. H. (2018). Highly stable novel silica/ chitosan support for $\beta$-galactosidase immobilization for application in dairy technology. Food Chemistry, 246, 343-350. https://doi.org/10.1016/j. foodchem.2017.11.026.

Rimola, A., Costa, D., Sodupe, M., Lambert, J.-F., \& Ugliengo, P. (2013). Silica surface features and their role in the adsorption of biomolecules: Computational modeling and experiments. Chemical Reviews, 113(6), 4216-4313. https://doi.org/10.1021/ cr3003054.

Schöffer, J.d. N., Klein, M. P., Rodrigues, R. C., \& Hertz, P. F. (2013). Continuous production of $\beta$-cyclodextrin from starch by highly stable cyclodextrin glycosyltransferase immobilized on chitosan. Carbohydrate Polymers, 98(2), 1311-1316. https://doi.org/10.1016/j.carbpol.2013.07.044.

Schöffer, J.d. N., Matte, C. R., Charqueiro, D. S., de Menezes, E. W., Costa, T. M. H., Benvenutti, E. V., Rodrigues, R. C., \& Hertz, P. F. (2017). Directed immobilization of CGTase: The effect of the enzyme orientation on the enzyme activity and its use in packed-bed reactor for continuous production of cyclodextrins. Process Biochemistry, 58, 120-127. https://doi.org/10.1016/j.procbio.2017.04.041.

Sheldon, R. A., \& van Pelt, S. (2013). Enzyme immobilisation in biocatalysis: Why, what and how. Chemical Society Reviews, 42(15), 6223-6235. https://doi.org/10.1039/ c3cs60075k.

Sigurdardóttir, S. B., Lehmann, J., Ovtar, S., Grivel, J.-C., Negra, M. D., Kaiser, A., \& Pinelo, M. (2018). Enzyme immobilization on inorganic surfaces for membrane reactor applications: Mass transfer challenges, enzyme leakage and reuse of materials. Advanced Synthesis \& Catalysis, 360(14), 2578-2607. https://doi.org/ 10.1002/adsc. 201800307.

Urrutia, P., Bernal, C., Wilson, L., \& Illanes, A. (2018). Use of chitosan heterofunctionality for enzyme immobilization: $\beta$-galactosidase immobilization for galacto-oligosaccharide synthesis. International Journal of Biological Macromolecules, 116, 182-193. https://doi.org/10.1016/j.ijbiomac.2018.04.112.

Webb, P. A., \& Orr, C. (1997). Analytical methods in fine particle technology (1st ed.). Norcross: Micromeritics Instrument Corporation.

Wolf, M., \& Paulino, A. T. (2019). Full-factorial central composite rotational design for the immobilization of lactase in natural polysaccharide-based hydrogels and hydrolysis of lactose. International Journal of Biological Macromolecules, 135, 986-997. https://doi.org/10.1016/j.ijbiomac.2019.06.032.

Xavier, J. R., Ramana, K. V., \& Sharma, R. K. (2018). $\beta$-galactosidase: Biotechnological applications in food processing. Journal of Food Biochemistry, 42(5), e12564. https:// doi.org/10.1111/jfbc.12564.

Xie, W., \& Zang, X. (2017). Covalent immobilization of lipase onto aminopropylfunctionalized hydroxyapatite-encapsulated- $\gamma$ - $\mathrm{Fe} 2 \mathrm{O} 3$ nanoparticles: A magnetic biocatalyst for interesterification of soybean oil. Food Chemistry, 227, 397-403. https://doi.org/10.1016/j.foodchem.2017.01.082.

Xu, M., Ji, D., Deng, Y., \& Agyei, D. (2020). Preparation and assessment of cross-linked enzyme aggregates (CLEAs) of $\beta$-galactosidase from Lactobacillus leichmannii 313. Food and Bioproducts Processing, 124, 82-96. https://doi.org/10.1016/j. fbp. 2020.08.004.

Zucca, P., \& Sanjust, E. (2014). Inorganic materials as supports for covalent enzyme immobilization: methods and mechanisms. Molecules, 19, 14139-14194. https://doi. org/10.3390/molecules190914139. 